\title{
UJI EFFECT SIZE MODEL PEMBELAJARAN SCRAMBLE DENGAN MEDIA VIDEO TERHADAP HASIL BELAJAR FISIKA PESERTA DIDIK KELAS X MAN 1 PESISIR BARAT
}

\author{
Rahma Diani $^{1}$, Yuberti ${ }^{2}$, Shella Syafitri ${ }^{3}$ \\ 1,2,3Pendidikan Fisika IAIN Raden Intan Lampung, e-mail: rahmadiani@ radenintan.ac.id
}

\begin{abstract}
The purpose of this study was to determine the effect size scramble learning model with video media on Physics students learning outcomes of class X MAN 1 Pesisir Barat on the measurement material. The research method used was a quasi experimental design with nonequivalent control group design. The survey results revealed that the normality test of the experimental class $L_{\text {count }}=0.161052$ and class control while $L_{\text {count }}=0.149135 L_{\text {table }}=0.1726$. Terms of normality test $L_{\text {count }}<L_{\text {table }}$ then normally distributed data. To test the homogeneity of $F_{\text {count }}<F_{\text {table }}=1.166<1.96$ then the data homogeneous. Test hypotheses obtained $t_{\text {count }}>t$ table $=6.4>1.708$ means that there are significant scramble learning model with video media to the learning outcomes of students subject matter physics measurements in class X MAN 1 Pesisir Barat. Furthermore, the effect size obtained results of 0.8. These results indicate that the learning model Scramble with video media can influence the outcome of physics students learn as much as $79 \%$.
\end{abstract}

\begin{abstract}
Abstrak: Tujuan penelitian ini adalah untuk mengetahui effect size model pembelajaran scramble dengan media video terhadap hasil belajar Fisika peserta didik kelas X MAN 1 pesisir barat pada materi pengukuran. Metode penelitian yang di gunakan adalah quasi eksperimental dengan desain nonequivalent control group design. Dari hasil penelitian diketahui bahwa uji normalitas pada kelas eksperimen $\mathrm{L}_{\text {hitung }}=0,161052$ dan kelas kontrol $\mathrm{L}_{\mathrm{hitung}}=0.149135$ sedangkan $\mathrm{L}_{\text {tabel }}=0,1726$. Syarat uji normalitas $\mathrm{L}_{\text {hitung }}<\mathrm{L}_{\text {tabel }}$ maka data terdistribusi normal. Untuk uji homogenitas, $\mathrm{F}_{\text {hitung }}<\mathrm{F}_{\text {tabel }}=1,166<$ 1,96 maka data homogen. Uji hipotesis didapatkan $t_{\text {hitung }}>t_{\text {tabel }}=6,4>1,708$ artinya, terdapat pengaruh model pembelajaran scramble dengan media video terhadap hasil belajar Fisika peserta didik materi pokok pengukuran di kelas X MAN 1 Pesisir Barat. Selanjutnya, diperoleh hasil uji effect size sebesar 0,8. Hasil ini menunjukkan bahwa model pembelajaran Scramble dengan media video dapat mempengaruhi hasil belajar fisika peserta didik sebanyak $79 \%$.
\end{abstract}

C 2016 Pendidikan Fisika FTK IAIN Raden Intan Lampung

Kata kunci: effect size, hasil belajar, media video, model pembelajaran scramble

\section{PENDAHULUAN}

Effect sizes are the most important outcome of empirical studies. Most articles on effect sizes highlight their importance to communicate the practical significance of results (Lakens, 2013). Using specific effect size statistics, or even the concept of magnitude of findings as different from statistical significance, is clearly not yet integral to conducting and reporting educational research (McMillan \& Foley, 2011). While statistical tests of significance indicate the likelihood that results would differ by chance (and are depend upon sample size), effect size measurements tell us the relative importance or magnitude of the treatment (Springer, 2006).

Effect size menunjukkan sejauh mana suatu variabel mempengaruhi variabel lain dalam suatu penelitian atau menunjukkan seberapa efektif suatu variabel mempengaruhi variabel lainnya. Effect size merupakan ukuran mengenai signifikansi praktis hasil penelitian yang berupa ukuran besarnya korelasi atau perbedaan, atau efek dari suatu variabel pada variabel lain (Santoso, 2010). Effect size juga merupakan besarnya perbedaan maupun hubungan, yang bebas dari pengaruh besarnya sampel 
(Olejnik, S \& Algina, 2003). Effect size measures are the common currency of meta-analysis studies that summarize the findings from a specific area of research (Lee, 2000).

Belajar adalah suatu proses yang dilalui peserta didik untuk memperoleh pengalaman baru melalui mengalami atau latihan. Untuk memperoleh prestasi/hasil belajar yang baik, proses pembelajaran harus dilakukan dengan baik dan tepat. Hasil belajar yang bermutu hanya mungkin dicapai melalui proses belajar yang bermutu (Fayakun \& P, 2015). Proses belajar mengajar merupakan suatu proses serangkai perbuatan pendidik dan peserta didik atas dasar hubungan timbal balik yang berlangsung dalam situasi edukatif untuk mencapai tujuan tertentu (Dwi, W, \& H, 2015). Proses belajar bisa terjadi dimana saja dan kapan saja, baik dilingkungan sekolah, rumah, maupun masyarakat. Perubahan tingkah laku peserta didik dapat diketahui dari hasil belajar yang didapatkan, baik pada ranah pengetahuan (kongnitif), sikap (afektif), maupun keterampilan (psikomotor).

Mata pelajaran Fisika merupakan mata pelajaran yang ditakuti oleh para peserta didik (Afifah, Murniati, \& Susilawati, 2013). Kecenderungan ini biasanya berawal dari pengalaman belajar yang memberikan kesan bahwa pelajaran Fisika adalah pelajaran berat dan serius tidak jauh dari persoalan konsep, pemahaman konsep, penyelesaian soal yang rumit melalui pendekatan matematis sampai kegiatan praktikum yang menuntut mereka melakukan segala sesuatunya dengan sangat teliti dan cenderung membosankan (Tri et al., 2012).

Fisika merupakan salah satu mata pelajaran dalam rumpun sains yang sangat erat kaitannya dengan kehidupan sehari-hari manusia (Saregar, 2016). Pembelajaran Fisika adalah pembelajaran tentang gejala-gejala alam, langit dan bumi (alam sekitar), dengan tujuan utama untuk mencari keteraturan dalam pengamatan manusia pada alam sekitarnya. Fisika menjelaskan berbagai gejala fisis fenomena yang terjadi di alam, baik secara teori maupun perhitungan (Diani, 2015).

Pembelajaran Fisika bisa dimulai dari diri pendidik dengan memberikan pengajaran yang lebih mudah dipahami dan dimengerti oleh peserta didik, pemilihan model, dan media pembelajaran membantu peserta didik untuk lebih mudah memahami materi pembelajaran. Model pembelajaran yang diterapkan harus sesuai dengan situasi, kondisi dan kebutuhan peserta didik. Yang tidak kalah penting dalam pembelajaran adalah pemilihan media pembelajaran, media pembelajaran yang interaktif akan membantu proses penyampaian informasi atau materi dengan baik dan mudah dimengerti. Media pembelajaran membantu memantapkan pengetahuan pada benak para peserta didik serta menghidupkan pelajaran yang dapat mempermudah pemahaman siswa (Diani, 2016).

Namun kenyataannya, dalam proses pembelajaran masih ditemukan pembelajaran yang bersifat teacher centered, text book oriented, dan pendidik menggunakan media belajar seadanya atau malah tidak menggunakan media. Pendidik menyampaikan materi sesuai dengan apa yang ada pada buku ajar yang digunakan saja, tanpa memberikan kesempatan atau memfasilitasi siswa untuk bereksplorasi lebih jauh. Keadaan seperti ini siswa menjadi kurang aktif, minat belajar kurang, siswa tidak bisa belajar secara mandiri tanpa adanya pendidik, dan hasil belajar yang rendah.

Nilai rata-rata ulangan harian peserta didik kelas $\mathrm{X}$ semester satu Tahun Ajaran 2014/2015 pada pokok bahasan pengukuran adalah $\leq 75$. Jumlah peserta didik yang belum tuntas mencapai $100 \%$. Hal tersebut menunjukkan bahwa hasil belajar peserta 
didik pada pelajaran Fisika masih sangat rendah jika dibandingkan dengan kriteria ketuntasan minimal, yaitu 75 untuk individu. Sedangkan keberhasilan pembelajaran ditandai dengan ketuntasan belajar bila $80 \%$ dari peserta didik satu kelas telah memperoleh nilai 75 keatas. Rendahnya hasil belajar peserta didik ini disebabkan oleh pemilihan model dan media pembelajaran yang tidak sesuai. Dapat dilihat bahwa model pembelajaran dapat berpengaruh terhadap hasil belajar peserta didik, memilih suatu model mengajar, harus sesuai dengan realitas yang ada dan situasi kelas yang ada, serta pandangan hidup yang akan dihasilkan dari proses kerjasama dilakukan antara guru dan peserta didik (Jihad \& Haris, 2012).

Salah satu model pembelajaran yang dapat digunakan adalah model pembelajaran. Model pembelajaran Scramble merupakan salah satu model pembelajaran yang dapat meningkatkan konsentrasi dan kecepatan berfikir sisiwa, (Huda, 2013) model ini mengajak siswa untuk mencari jawaban terhadap suatu pertanyaan atau pasangan suatu konsep secara kreatif dengan cara menyusun huruf- huruf yang disusun secara acak sehingga membentuk suatu jawaban/pasangan konsep yang dimaksud.

Beberapa penelitian terkait model pembelajaran Scramble menunjukkan bahwa model Scramble memiliki pengaruh yang positif pada pembelajaran. Model pembelajaran Scramble mampu mempengaruhi hasil belajar peserta didik, hal ini dapat dilihat dari keaktifan siswa dalam kelompok untuk menyelesaikan kartu soal dan lebih tertantang untuk teliti dalam menjawab karena jawaban sudah tersedia (Handayani, Lestari, \& Dahlia, 2014).

Media yang dipilih untuk untuk digunakan adalah video. Salah satunya dengan media pembelajaran digital yang dapat digunakan dalam pembelajaran seperti media video (Nurcahyo, 2013). Media pembelajaran berupa media video/animasi ini penting karena tipe belajar setiap siswa sangat heterogen, ada siswa yang tipe belajarnya auditif, visual dan kinestetis (Juriah, 2016).

Widiantari, Syahruddin, \& Widiana (2012), dalam penelitiannya juga mengemukakan bahwa hasil belajar IPA peserta didik baik pada kelompok yang belajar menggunakan model pembelajaran Scramble berbantu media video maupun dengan siswa yang belajar menggunakan model pembelajaran konvesional. Secara deskriptif, kelompok yang belajar menggunakan model pembelajaran Scramble berbantu media video memiliki rata- rata hasil belajar sebesar 22,26, sedangkan kelompok yang belajar dengan menggunakan model pembelajaran konvesional memiliki skor rata- rata hasil belajar sebesar 13,56.

\section{LANDASAN TEORI}

1. Pembelajaran Fisika

Fisika adalah ilmu pengetahuan yang paling mendasar, karena berhubungan dengan prilaku dan struktur benda. (Giancoli, 2001). Fisika adalah ilmu eksperimental. Fisika merupakan materi, energi, dan fenomena atau gejala alam, baik yang bersifat makroskopis (berukuran besar) maupun yang bersifat mikroskopis (berukuran kecil) (Primavera, \& Permana, 2014). Dalam belajar Fisika, yang pertama dituntut adalah kemampuan untuk memahaman konsep, prinsip maupun hukum-hukum, kemudian diharapkan peserta didik mampu menyusun kembali dalam bahasanya sendiri sesuai dengan tingkat kematangan dan perkembangan intelektualnya.

\section{Model Pembelajaran Scremble}

Model pembelajran Scramble merupakan salah satu model pembelajaran yang dapat meningkatkan 
konsentrasi dan kecepatan berpikir peserta didik. Metode ini mengharuskan peserta didik untuk menggabungkan otak kanan dan otak kiri. (Huda, 2013). Dalam pembelajaran scramble ini keaktifan dan kreatifitas siswa menjadi hal yang penting karena tanpa hal tersebut siswa menjadi tidak berkembang (Tri \& L, 2009). Model pembelajaran scramble mampu mengoptimalkan siswa untuk berpikir lebih kreatif dalam menemukan dan menyusun suatu pola atau struktur yang baru.

Sintak pembelajaran Scramble dapat diterapkan dengan mengikuti tahap- tahap berikut ini (Huda, 2013).

a. Pendidik menyajikan materi sesuai topik. Misalnya pendidik menyajikan materi pelajaran tentang "Tata Surya".

b. Setelah selesai menjelaskan tentang Tata Surya, pendidik membagikan lembar kerja dengan jawaban yang diacak susunanya.

c. Pendidik member durasi tertentu untuk pengerjaan soal.

d. Peserta mengerjakan soal berdasarkan waktu yang telah ditentukan pendidik.

e. Pendidik mengecek durasi waktu sambil memeriksa pekerjaan peserta didik.

f. Jika waktu pengerjaan sudah habis, peserta didik wajib mengumpulkan lembar jawaban kepada pendidik. Dalam hal ini baik peserta didik yang selesai maupun belum selesai harus mengumpulkan jawaban.

g. Pendidik melakukan penilaian, penilaian dilakukan berdasarkan seberapa cepat peserta didik mengerjakan soal dan seberapa banyak soal yang bisa peserta didik kerjakan dengan benar.

h. Pendidik memberikan apresiasi terhadap peserta didik yang berhasil, dan memberikan semangat kepada peserta didik yang belum cukup berhasil menjawab dengan cepat dan benar

\section{Media Video}

Media pembelajaran merupakan hal yang penting untuk berlangsungnya suatu pembelajaran di kelas, pembelajaran yang kreatif, komunikatif, dan inovatiflah yang dapat mendukung dalam meningkatkan hasil belajar peserta didik (Dwi, W, \& H, 2015). Kedudukan media pembelajaran adalah sebagai alat penghubung antara pengajar dengan peserta didik (Handziko \& Suyanto, 2015). Media video pembelajaran merupakan jenis media audio/visual yang menyajikan pesanpesan pembelajaran baik yang berisi konsep, prinsip, prosedur, teori aplikasi pengetahuan untuk membantu pemahaman terhadap suatu materi pembelajaran dalam bentuk gambar dan suara. Akan terjadi peningkatan prestasi belajar setelah menggunakan teknologi informasi atau video pembelajaran yang diambil dari internet (Noviyanto, Nengsih, \& Rosyidatun, 2015). Peranan media video pembelajaran sebagai berikut:

a. Dapat menarik perhatian peserta didik sehingga dapat menumbuhkan motivasi belajar.

b. Memperjelas makna bahan pengajaran sehingga mudah dipahami siswa.

c. Metode pengajaran lebih bervariasi. Siswa lebih banyak melakukan kegiatan belajar

\section{Hasil Belajar}

Belajar bukan suatu tujuan tetapi merupakan suatu proses untuk mencapai tujuan. Belajar itu sendiri merupakan suatu proses dari seseorang yang berusaha untuk memperoleh suatu bentuk perubahan prilaku yang relative menetap. Belajar merupakan langkahlangkah atau prosedur yang ditempuh. Bukti bahwa seseorang telah belajar 
ialah terjadinya perubahan tingkah laku pada seseorang tersebut.

Hasil belajar dinyatakan dalam klasifikasi yang dikembangkan oleh Benyamin S Bloom, dalam sistem pendidikan nasional rumusan tujuan pendidikan mengacu pada klasifikasi hasil belajar dari Bloom yang secara garis besar yaitu aspek kognitif, aspek afektif dan aspek psikomotor (Widodo \& Widayanti, 2012). Dalam penelitian ini hasil belajar yang diteliti adalah hasil belajar kognitif.

\section{METODE PENELITIAN}

Metode penelitian yang di gunakan adalah quasi eksperimental (Eksperimen Semu). Model desain eksperimen ini mempunyai kelompok kontrol, tetapi tidak dapat berfungsi sepenuhnya untuk mengontrol variabel-variabel luar yang mempengaruhi pelaksanaan eksperimen. (Sugiyono, 2013) dalam penelitian ini digunakan desain nonequivalent control group design, desain ini hampir sama dengan pretest-posttes countrol group desain hanya pada desain ini kelompok eksperimen maupun kelompok konrol tidak dipilih secara random. Populasi tersebut terdiri atas 8 kelas yaitu, IPA $(1,2,3)$ dan IPS $(1,2,3,4,5)$. Sampel dalam penelitian ini hanya diambil pada peserta didik kelas X IPA 2 sebagai kelas eksperimen dan X IPA 3 sebagai kelas kontrol dengan jumlah peseta didik pada setiap kelas 25 peserta didik.

Teknik sampling pada penelitian ini dialakukan dengan teknik purposive sampling merupakan teknik penentuan sampel dengan pertimbangan khusus sehingga layak dijadikan sample (Noor, 2011). Teknik ini dilakukan dengan cara mengambil subjek bukan didasarkan atas strata, random, atau daerah tetapi didasarkan atas adanya tujuan dan

Tabel 1. Interpretasi nilai effect size

\begin{tabular}{cccccc} 
Effect & Percentage of & Rank of person & Probability that & Equivalent & Probability that \\
Size & control group & in a control & you could guess & correlation, $r$ & person from \\
& who would be & group of 25 & which group a & (=Difference in & experimental \\
below average & who would be & person was in & percentage & group will be \\
person in & equivalent to & from & 'successful' in & higher than \\
\hline
\end{tabular}

pertimbngan tertentu. Teknik ini berdasarkan pada ciri- ciri atau sifatsifat tertentu yang diperkirakan mempunyai sangkut paut erat dengan ciri- ciri atau sifat- sifat yang ada dalam populasi yang sudah diketahui sebelumnya. Adapun teknik pengumpulan data yang digunakan adalah sebagai berikut: tes, observasi, dan dokumentasi.

Instrumen penelitian yang digunakan dalam penelitian ini adalah tes objektif dan observasi. Lembar tes objektif terdiri dari 40 soal dengan lima alternatif jawaban pada setiap butir soalnya. Sebelum digunakan, soal tes telah di uji validitas, reliabilitas, tingkat kesukaran, daya beda, dan keberfungsian pengecoh.

Instrument yang digunakan selanjutnya adalah lembar observasi yang bertujuan untuk melihat aktivitas peserta didik yang sedang terjadi secara runtut dari awal sampai akhir dan untuk melihat keterlaksanaan model pembelajaran. Data observasi diukur menggunakan skala liket

Teknik Analisis data yang dilakukan adalah uji normalitas, uji homogenitas, uji hipotesis dengan uji $\mathrm{t}$ dan uji hasil observasi. Uji effect size menggunakan rumus (Hake, 2002):

$$
d=\left(M_{A}-M_{B}\right) /\left[\left(S d_{A}^{2}+S d_{B}^{2}\right) / 2\right]^{1 / 2}
$$

dengan:

$\mathrm{d} \quad=$ Effect Size

$\mathrm{M}_{\mathrm{A}}=$ rata-rata Gain kelas eksperimen

$\mathrm{M}_{\mathrm{B}}=$ rata-rata Gain kelas kontrol

$S d_{A}=$ standar deviasi kelas eksperimen

$S d_{B}=$ standar deviasi kelas kontrol

Setelah diperoleh, nilai $d$ kemudian di interpretasi dengan ketentuan (Coe, 2002): 


\begin{tabular}{|c|c|c|c|c|c|}
\hline & $\begin{array}{l}\text { experimental } \\
\text { group }\end{array}$ & $\begin{array}{l}\text { the average } \\
\text { person in } \\
\text { experimental } \\
\text { group }\end{array}$ & $\begin{array}{l}\text { knowledge of } \\
\text { their 'score'. }\end{array}$ & $\begin{array}{l}\text { each of the two } \\
\text { groups, BESD) }\end{array}$ & $\begin{array}{l}\text { person from } \\
\text { control, if both } \\
\text { chosen at } \\
\text { random } \\
\text { (=CLES) }\end{array}$ \\
\hline 0.0 & $50 \%$ & $13^{\text {th }}$ & 0.50 & 0.00 & 0.50 \\
\hline 0.1 & $54 \%$ & $12^{\text {th }}$ & 0.52 & 0.05 & 0.53 \\
\hline 0.2 & $58 \%$ & $11^{\text {th }}$ & 0.54 & 0.10 & 0.56 \\
\hline 0.3 & $62 \%$ & $10^{\text {th }}$ & 0.56 & 0.15 & 0.58 \\
\hline 0.4 & $66 \%$ & $9^{\text {th }}$ & 0.58 & 0.20 & 0.61 \\
\hline 0.5 & $69 \%$ & $8^{\text {th }}$ & 0.60 & 0.24 & 0.64 \\
\hline 0.6 & $73 \%$ & $7^{\text {th }}$ & 0.62 & 0.29 & 0.66 \\
\hline 0.7 & $76 \%$ & $6^{\text {th }}$ & 0.64 & 0.33 & 0.69 \\
\hline 0.8 & $79 \%$ & $6^{\text {th }}$ & 0.66 & 0.37 & 0.71 \\
\hline 0.9 & $82 \%$ & $5^{\text {th }}$ & 0.67 & 0.41 & 0.74 \\
\hline 1.0 & $84 \%$ & $4^{\text {th }}$ & 0.69 & 0.45 & 0.76 \\
\hline 1.2 & $88 \%$ & $3^{\text {rd }}$ & 0.73 & 0.51 & 0.80 \\
\hline 1.4 & $92 \%$ & $2^{\text {nd }}$ & 0.76 & 0.57 & 0.84 \\
\hline 1.6 & $95 \%$ & $1^{\mathrm{st}}$ & 0.79 & 0.62 & 0.87 \\
\hline 1.8 & $96 \%$ & $1^{\mathrm{st}}$ & 0.82 & 0.67 & 0.90 \\
\hline 2.0 & $98 \%$ & $\begin{array}{c}1^{\text {st }}\left(\text { or } 1^{\text {st }} \text { out of }\right. \\
44)\end{array}$ & 0.84 & 0.71 & 0.92 \\
\hline 2.5 & $99 \%$ & $\begin{array}{c}1^{\text {st }}\left(\text { or } 1^{\text {st }} \text { out of }\right. \\
160)\end{array}$ & 0.89 & 0.78 & 0.96 \\
\hline 3.0 & $99.9 \%$ & $\begin{array}{c}1^{\text {st }}\left(\text { or } 1^{\text {st }} \text { out of }\right. \\
740)\end{array}$ & 0.93 & 0.83 & 0.98 \\
\hline
\end{tabular}

HASIL DAN PEMBAHASAN

Masing - masing kelas terdiri dari 25 peserta didik. Kelas eksperimen diterapkan model pembelajaran Scramble berbantu media video, sedangkan di kelas kontrol diterapkan model konvensional. dari 40 soal yang telah diujicobakan didapatkan 20 soal untuk tes akhir. Hasil belajar posstes yang diperoleh oleh kelompok eksperimen dengan 20 soal mencapai rata- rata 77 sedangkan kelompok kontrol 70,6. Nilai maksimal kelas eksperimen yang diperoleh peserta didik adalah 90, dan minimal adalah nilai 60 . Sedangkan kelompok kontrol nilai maksimal 80, dan nilai minimum 60 .
Lebih jelasnya dapat dilihat pada table 1 dibawah ini.

Tabel 2. Distribusi hasil belajar postes kelompok eksperimen dan kelompok control.

\begin{tabular}{cccccc}
\hline No & \multirow{2}{*}{ Perolehan } & \multicolumn{2}{c}{ Eksperimen } & \multicolumn{2}{c}{ Kontrol } \\
\cline { 3 - 6 } & & f & persentase & f & persentase \\
\hline $\mathbf{1}$ & 60 & 1 & $4 \%$ & 4 & $16 \%$ \\
\hline $\mathbf{2}$ & 65 & - & - & 5 & $20 \%$ \\
\hline $\mathbf{3}$ & 70 & 5 & $20 \%$ & 5 & $20 \%$ \\
\hline $\mathbf{4}$ & 75 & 6 & $24 \%$ & 6 & $24 \%$ \\
\hline $\mathbf{5}$ & 80 & 9 & $36 \%$ & 5 & $20 \%$ \\
\hline $\mathbf{6}$ & 85 & 3 & $12 \%$ & - & - \\
\hline $\mathbf{7}$ & 90 & 1 & $4 \%$ & - & - \\
\hline \multicolumn{7}{c}{ Jumlah } & 25 & $100 \%$ & 25 & $100 \%$ \\
\hline
\end{tabular}

Berdasarkan tabel 1, diketahui bahwa nilai Fisika kelas Eksperimen dan kelas kontrol berbeda, penerapan model pembelajaran Scramble dengan media 
video di MAN 1 Pesisir Barat mampu mempengaruhi hasil belajar peserta didik.

Uji normalitas dilakukan untuk atau tidak. Hasil uji normalitas disajikan pada tabel 3 .

Tabel 3. Uji Normalitas mengetahui data berdistribusi normal

Setelah data dikatakan normal dan homogen, maka hipotesis dapat diuji untuk mengetahui adakah pengaruh model pembelajaran Scramble dengan media video terhadap hasil belajar Fisika peserta didik pada materi Pengukuran di kelas X MAN 1 Pesisir Barat. Untuk mengetahui ada tidaknya perbedaan perlakuan maka digunakan rumus uji t. jika nilai thitung $>t_{\text {tabel }}$ berarti terdapat pengaruhperlakuan. Berdasarkan dari data yang didapat bahwa $t_{\text {hitung }}=6,4$ dan $t_{\text {tabel }}=2,064$. Karena $t_{\text {hitung }}>t_{\text {tabel }}=6,4>$

2 Kontrol $0.149135 \quad 0,1726 \quad$ Ho 2,064 maka Ho ditolak dan $\mathrm{H}_{1}$ diterima.
diterima Ini menunjukkan bahwa terdapat pengaruh model pembelajaran Scramble Dari hasil uji normalitas diketahui bahwa data terdistribusi normal karena $\mathrm{L}_{\text {hitung }}<\mathrm{L}_{\text {tabel }}=0.161052<0,1726$ dan $0.149135<0,1726$.

Selanjutnya dilakukan uji homogenitas. Dengan taraf signifikan $\alpha$ $=0,05$ diperoleh $\mathrm{F}_{\mathrm{tab}}=1,96$ (interpolasi) dan dari hasil perhitungan diperoleh $\mathrm{F}_{\text {hit }}$ $=1,166$ Berdasarkan hasil tersebut terlihat bahwa $\mathrm{F}_{\text {hit }}<\mathrm{F}_{\text {tab. }}$. Hal ini berarti bahwa $\mathrm{H}_{0}$ diterima. Jadi dapat disimpulkan bahwa sampel berasal dari populasi yang homogen artinya peserta didik dari kelas sampel memiliki kemampuan yang setara. Kehomogenitasan sampel ini menyempurnakan prasyarat yang dibutuhkan untuk melakukan uji hipotesis menggunakan uji t-tes. dengan media video terhadap hasil belajar Fisika peserta didik dikelas $\mathrm{X}$ MAN 1 Pesisir Barat pada materi pengukuran.

Selanjutnya, dari hasil uji hipotesis yang diperoleh. Kemudian dilakukan uji effect size. Hasil yang diperoleh adalah d $=0,8$. Hasil ini kemudian di interpretasi dengan menggunakan tabel 1. Diperoleh bahwa model scramble dengan media video mempengaruhi hasil belajar siswa sebanyak $79 \%$.

Teknik pengumpulan data selanjutnya yang digunakan adalah dengan menggunakan teknik observasi. Hasil observasi disajikan pada Tabel 4.

Tabel 4. Persentase Hasil Observasi

\begin{tabular}{cc}
\hline \multicolumn{2}{c}{ Observasi Kelas Eksperimen } \\
\hline $\begin{array}{c}\text { Keterlaksanaan model scramble } \\
\text { dengan media video }\end{array}$ & $\begin{array}{c}\text { Aktivitas Peserta didik dalam } \\
\text { Pembelajaran }\end{array}$ \\
\hline$\frac{\text { jumlah skor jawaban pengamat }}{\text { jumlah shor maksimum }} \times 100 \%$ & $\frac{\text { jumlah skor jawaban pengamat }}{\text { jumlah skor maksimum }} \times 100 \%$ \\
$=\frac{\mathrm{aa}}{45} \times 100 \%=60 \%$ & $=\frac{2 \mathrm{a}}{\mathrm{a} 0} \times 100=76,6 \%$ \\
\hline
\end{tabular}

Dari hasil perhitungan, persentase keterlaksanaan model scramble dengan media video kelas eksperimen sebesar 60 $\%$ dan aktivitas peserta didik dalam pembelajaran sebesar $76,6 \%$. Hal ini menunjukkan bahwa pendidik memberikan pembelajaran yang cukup baik dengan menggunakan model pembelajaran Scrambel berbantu media video.

Faktor yang mempengaruhi perbedaan hasil belajar peserta didik kelas eksperimen dan kontrol adalah model pembelajaran dan media 
pemeblajaran yang digunakan penulis dalam pembelajaran. Berdasarkan deskripsi data hasil penelitian, penerapan model pembelajaran Scramble dengan media video mempengaruhi hasil belajar fisika peserta didik di MAN 1 Pesisir Barat pada materi pengukuran.

Model pembelajaran Scramble merupakan salah satu metode pembelajaran yang dapat meningkatkan konsentrasi dan kecepatan berpikir peserta didik (Huda, 2013). Sehingga penerapan model pembelajaran Scramble dapat meningkatkan aktivitas dan hasil belajar peserta didik. Dalam pembelajaran, peserta didik akan berdiskusi dalam mencari jawaban yang tepat, sesuai dengan soal yang telah diberikan pendidik. Kemudian siswa mengkoreksi (membolak-balik huruf) pilihan jawaban yang diberikan sehingga menjadi jawaban yang tepat/benar. Hal ini membuat peserta didik menjadi senang dan termotivasi untuk memahami materi dan menjawab pertanyaan yang diberikan pendidik.

Melalui bantuan media video peserta didik dapat lebih cepat memahami materi yang dipelajarinya (Widiantari, Syahruddin, \& Widiana, 2012). Pembelajaran dengan menggunakan media video akan menjadi lebih menarik sehingga peserta didik akan antusias dalam mengikuti pembelajaran.

Model pembelajaran Scramble dengan media video akan membuat peserta didik terbantu dalam mencari jawaban, mendorong peserta didik untuk belajar mengerjakan soal, semua peserta didik dapat terlibat aktif. Dengan meningkatnya aktivitas belajar siswa, maka hasil belajar siswapun turut meningkat (Diani, 2015). kegiatan pembelajaran ini mendorong pemahaman peserta didik terhadap materi pembelajaran dengan bantuan teman- teman sesama peserta didik, dan adanya pembelajaran sikap disiplin.
Berdasarkan pemaparan diatas dapat dilihat bahwa secara konseptual dan operasional antara model scramble dan konvensional berbeda, sehingga hasil pembelajaran dari kedua model ini pun akan berbeda. Hasil pembelajaran yang baik dikarenakan proses pembelajaran yang terlaksana dengan baik, proses pembelajaran menggunakan Model pembelajaran Scramble dapat dilihat dari hasil pengamatan yang dilakukan berada pada kategori cukup tinggi. Lembar observasi ini bertujuan untuk untuk melihat keterlaksanaan model pembelajaran yang dilakukan oleh pendidik dan aktivitas belajar peserta didik secara runtut dari awal sampai akhir pembelajaran.

\section{SIMPULAN DAN SARAN Simpulan}

Berdasarkan hasil analisis dan pengolahan data maka disimpulkan bahwa terdapat pengaruh model pembelajaran Scramble dengan media video terhadap hasil belajar peserta didik pada materi pengukuran kelas X MAN 1 Pesisir Barat, dengan $t_{\text {hitung }}=6,4$ dan $t_{\text {tabel }}$ $=2,064$. Karena $t_{\text {hitung }}>t_{\text {tabel }}=6,4>$ 2,064 maka Ho ditolak dan $\mathrm{H}_{1}$ diterima. Selanjutnya, diperoleh hasil uji effect size sebesar 0,8. Hasil ini menunjukkan kan bahwa model pembelajaran Scramble dengan media video dapat mempengaruhi hasil belajar fisika peserta didik sebanyak $79 \%$

\section{Saran}

1. Diharapkan pendidik dapat memilih model pembelajaran disertai pemilihan media yang tepat agar mengefektifkan aktifitas belajar peserta didik sehingga berpengaruh terhadap hasil belajar peserta didik yang baik.

2. Sebaiknya guru membangun komunikasi yang baik dengan siswa agar proses belajar tidak kaku dan pasif 
3. Peserta didik sebaiknya tidak perlu ragu dan takut menuangkan ide-ide kreatifnya untuk menyelesaikan berbagai soal-soal Fisika.

4. Model pembelajaran Scramble bisa dimanfaatkan oleh guru-guru sebagai salah satu alternative dalam proses pembelajaran khususnya di MAN 1 Pesisir Barat.

\section{DAFTAR PUSTAKA}

Afifah, N., Murniati, N., \& Susilawati. (2013). Nur, Afifah, N.A.N Murniati, \& Susilawati, Penerapan Pendekatan Kontekstual Menggunakan Media Video Untuk Meningkatkan Hasil Belajar Fisika Pada Kelas XI RPL 1 SMK N 8 Semarang. Seminar Nasional 2nd Lonttar Physics Forum.

Coe, R. (2002). It's the Effect Size, Stupid What effect size is and why it is important. British Educational

Research Association annual con ference. Exeter.

Diani, R. (2015). Pengembangan Perangkat Pembelajaran Fisika Berbasis Pendidikan Karakter dengan Model Problem Based Instruction. Jurnal Ilmiah Pendidikan Fisika Al-Biruni Vol 4 No 2, 243-255.

Diani, R. (2015). Upaya Meningkatkan Aktivitas dan Hasil Belajar Fisika Siswa dengan Menggunakan Strategi Pembelajaran Aktif Tipe Inquiring Minds Want to Know di SMPO N 17 Kota Jambi. Jurnal Ilmiah Pendidikan Fisika Al-Biruni Vol 5 No 1, 133-143.

Diani, R. (2016). Pengaruh Pendekatan Saintifik Berbantukan LKS Terhadap Hasil Belajar Fisika Peserta Didik Kelas XI SMA PERINTIS 1 Bandar Lampung.
Jurnal Ilmiah Pendidikan Fisika Al-Biruni Vol 5 No 1, 83-93.

Dwi, H. K., W, S., \& H, L. (2015). Pengembangan Media Pembelajaran Video Tutorial Facebook Untuk Meningkatkan Hasil Belajar Siswa Pada Mata Pelajaran Pemasaran Online di Smk Negeri 3 Surakarta. Semiar Nasional Pendidikan Ekonomi \& Bisnis Fakultas Keguruan Keguruan dan Ilmu Pendidikan Universitas Sebelas Maret, (pp. 1-10). Surakarta.

Fayakun, M., \& P, J. (2015). Efektivitas Pembelajaran Fisika Menggunakan Model Kontekstual (Ctl) Dengan Metodepredict, Observe, Explain Terhadap Kemampuan Berpikir Tingkat Tinggi. Jurnal Pendidikan Fisika Indonesia, Vol 11 No 1, 49-58.

Giancoli, D. C. (2001). Fisika Edisi kelima Jilid 1, Jakarta: Erlangga. Jakarta: Erlangga.

Hake, R. (2002). Relationship Of Individual Student Normalized Learning Gains in Mechanics With Gender, Hight School Physics and Pretest Scores on Mathematics and Spatial Visualization. Jurnal Internasional Vol 1 No 1.

Handayani, S., Lestari, R., \& Dahlia. (2014). Pengaruh Model Pembelajaran Scramble Terhadap Hasil Belajar Siswa Kelas VII di SMP Negeri 2 Satu Atap Kepenuhan Hulu Tahun Pembelajarn. Retrieved from Program Studi Pendidikan Biologi, Fakultas Keguruan dan Ilmu Pendidikan, Universitas Pasir Pengaraian (On- Line), tersedia di: http:///ejournal.uup.ac.id/../362.

Handziko , R. C., \& Suyanto, S. (2015). Pengembangan Video Pembelajaran Suksesi Ekosistem 
Untuk Meningkatkan Motivasi Belajar dan Penguasaan Konsep Mahasiswa Biologi. Jurnal Inovasi Pendidikan IPA Vol 1 No 2, 212-224.

Huda, M. (2013). Model- Model Pengajaran dan Pembelajaran: Isu- Isu Metodis dan Praragtimatis. Yogyakarta: Pustaka Pelajar.

Jihad, A., \& Haris, A. (2012). Evaluasi Pembelajaran. Yogyakarta: Multi Pressido.

Juriah, \& Juanengsih, N. (2016). Juriah, Nengsih J., Pembelajaran Konstruktivisme Berbantu Media Video/Animasi untuk Meningkatkan Hasil Belajar Biologi Siswa Kelas X MIPA 3. EDUSAINS Vol 8 (1), 108-113.

Lakens, D. (2013). Calculating and reporting effect sizes to facilitate cumulative science : a practical primer for t-tests and ANOV as. Frontiers in Psychology VOl 4.

Lee, A. B. (2000). Effect Size Becker. Retrieved from www.bwgriffin.com.

McMillan, J. H., \& Foley, J. (2011). Reporting and Discussing Effect Size: Still the Road Less Traveled? Practical Assessment, Research \& Evaluation, Vol 16 No 14.

Ni Nyoman Widiantari, H.Syahruddin, dan I Wayan Widiana, Pengaruh Model Pembelajaran Scramble Berbantuan Media Video Terhadap Hasil Belajar IPA Siswa Kelas IV SD di Gugus V Kecamatan Buleleng, Jurusan PGSD, FIP Universitas Pendidikan Ganesha Singaraja, Indonesia, 2012.(On- line), tersedia di: http:///ejournal.undiksha.ac.id./in dex.php/jjpgsd/article/view/819 (23 Februari 2016).

Noor, J. (2011). Metodologi Penelitian. Jakarta: Prenadamedia.
Noviyanto, T., Juanengsih, N., \& Rosyidatun, E. S. (2015). Penggunaan Media Video Animasi Sistem Pernapasan Manusia Untuk Meningkatkan Hasil Belajar Biologi. EDUSAINS Vol 7 No 1, 57-63.

Nurcahyo, Y. D. (2013). Penggunaan Media Pembelajaran Video Tutorial Untuk Meningkatkan Hasil Belajar Siswa Teknik Gambar Bangunan SMK N 1 Seyegan Pada Mata Pelajaran Menggambar Dengan Autocad. Yogyakarta: Jurusan Pendidikan Teknik Sipil dan Perencanaan Fakultas Teknik Universitas Negeri Yogyakarta.

Olejnik, S, S., \& Algina, J. (2003). Generalized Eta and Omega Squared Statistics: Measures of Effect Size for Some Common Research Designs. Psychological Methods, 434-447.

Primavera, I. R. C., \& Permana, I. (2014). Pengaruh Media AudioVisual (Video) Terhadap Hasil Belajar Siswa Kelas XI Pada Konsep Elastisitas. Makalah disajikan dalam Prosiding Seminar Nasional Pendidikan IPA FITK UIN Syarif Hidayatullah Jakarta.

Santoso, A. (2010). Studi Dekriptif Effect Size Penelitian-penelitian di Fakultas Psikologi Universitas Sanata Dharma. Jurnal Penelitian, 1-17.

Saregar, A. (2016). Pembelajaran Pengantar Fisika Kuantum dengan Media PhET Simulation dan LKM Melalui Pendekatan Saintifik: Dampak pada Minat dan Penguasaan Konsep Mahasiswa. Jurnal Ilmiah Pendidikan Fisika Al-Biruni Vol 5 no 1, 53-60.

Springer, R. (2006). Using Effect Size in NSSE Survey Reporting. 
Research \& Practice in Assessment Vol 1.

Sugiyono. (2013). Metode Penelitian Pendidikan. Bandung: Alfabeta.

Tri, R., F, S. D., \& A, W. (2012). Penggunaan Model Pembelajaran Scramble untuk Peningkatan Motivasi Belajar IPA (Fisika) pada Siswa SMP Negeri 16 Purworejo Tahun Pelajaran 2011/2012. Radiasi Vol 1 No. 1, $1-10$.

Tri, W. E., \& L, M. (2009). Implementasi Model Pembelajaran Scramble Untuk Meningkatkan Kemampuan Sintesis (Synthesis) Pada Mata Pelajaran Biologi. Jurnal Pendidikan MIPA Vol. 1 No. 1 , 20-30.

Widiantari, N. N., Syahruddin, \& Widiana, I. W. (2012). Pengaruh Model Pembelajaran Scramble Berbantuan Media Video Terhadap Hasil Belajar IPA Siswa Kelas IV Sd di Gugus V Kecamatan Buleleng, Jurusan PGSD, FIP Universitas Pendidikan Ganesha Singaraja. Retrieved from http:///ejournal.undiksha.ac.id./in dex.php/jjpgsd/article/view/819.

Widodo, \& Widayanti, L. (2012). Peningkatan Aktivitas Belajar dan Hasil Belajar Siswa Dengan Metode Problem Based Learning Pada Siswa Kelas VIIA Mts Negeri Donomulyo Kulon Progo Tahun Pelajaran 2012/2013. Jurnal Fisika Indonesia No: 49, Vol XVII. 